\title{
Remarks on the Letter of the PAtriarch Theophylact to Tsar Peter in the Context of Certain Byzantine and Slavic Anti-heretic Texts
}

The oldest Byzantine testimony to the Bogomil movement is a letter of Theophylact, patriarch of Constantinople (933-956), to Peter, tsar of Bulgaria (927-969), from the middle of the $10^{\text {th }}$ century. The letter was discovered by the Benedictine Bernard de Montfaucon in the archives of the Biblioteca Ambrosiana as early as at the close of the $17^{\text {th }}$ century. It was for a long time misattributed to Theophylact of Ohrid (about 1050 - after 1126), the esteemed Byzantine writer and ecclesiastic; the authorship by the patriarch of Constantinople was established as late as at the turn of the $19^{\text {th }}$ and $20^{\text {th }}$ centuries ${ }^{1}$. In 1913 , the first edition of the letter appeared ${ }^{2}$; though burdened with errors in the Greek text and above all in the interpretation ${ }^{3}$, for a long time it remained (reprinted along with a commentary in V. Zlatarski's History of the Bulgarian State in the Middle Ages ${ }^{4}$ ) the sole edition of this critically important source for the history of neo-Manichaean medieval heresies. This only changed with the appearance of the study by I. Dujčev mentioned in the first footnote ${ }^{5}$.

\footnotetext{
1 For the history of the discovery of the letter and a survey of research on the text, cf.: I. DujčEv, L'epistola sui Bogomili del patriarcha Teofilatto, [in:] IDEM, Medioevo bizantinoslavo, vol. I, Roma 1965, p. 283-315 (text edition on p. 311-315). The article was first published in: Mélanges Eugène Tisserant, vol. II [= Studi e Testi, 232], Città del Vaticano 1964, p. 63-91.

2 Н.М. ПЕтровский, Письмо патриарха Константинопольского Феофилакта изарю Болгарии Пеmpy, [in:] ИОРЯС 18.3, 1913, p. 356-372.

3 I. DUJČEV, op. cit., p. 289-290.

4 В. ЗЛАТАРСКИ, История на българската държава през средните векове, vol. I.2, От славянизацията на държавата до падането на Първото изарство (852-1018), София 1927 (repr. София 1971), appendix XI, p. 840-845.

5 The text of the letter with a parallel Bulgarian translation was also published in: $F G H B$, vol. V, София 1964, p. 183-189. In this article, citations from the Greek text come from I. Dujčev's edition. Unless otherwise noted, the English text is cited from: Christian Dualist Heresies in the Byzantine World c. 650 - c. 1450, ed. J. Hamilton, B. Hamilton, assist. Y. Stoyanov, Manchester-New York 1998, p. $98-102$.
} 
Tsar Peter assumed the throne of his father, Symeon the Great, during a difficult period for the First Bulgarian Tsardom 6 . Superficially, the political situation appeared to be stable: emperor Romanus I Lecapenus confirmed both Peter's imperial title ( $\beta \alpha \sigma i \lambda \varepsilon \dot{s} \varsigma)$ and the autocephaly of the Bulgarian Church; a 30-year peace treaty between the Bulgarian and Byzantine empires was signed, corroborated by Peter's marriage with Romanus Lecapenus' granddaughter, Maria-Irene. On the other hand, however, strengthening the ties with Constantinople meant reinforcing Byzantine influence in the imperial court. The powerful neighbour had not forgotten the aggressive anti-Byzantine policy of Peter's father; resorting to diplomatic intrigues, Romanus and his successors were able to antagonize most of the nearby states against Bulgaria, damage its international standing, and in the long run - bring about the 1018 annihilation of the First Tsardom and the disestablishment of the Bulgarian autocephalous church. In this respect, Peter's reign could be viewed as the 'beginning of the end' of the Tsardom, although recent research has seen attempts to approach the sources from a different angle and appreciate the tsar's less easily noticeable effort towards a peaceful development ${ }^{7}$ of the state.

Peter I also looked after the interests of the young Bulgarian church. Himself a deeply pious man, presumably proclaimed a saint not long after death (feast day on 30 January $^{8}$, he strove to consolidate Christianity and was naturally vexed by the emergence of an alternative religious movement. Sometime before 950 a new dualist heresy arose in the Bulgarian lands, not yet referred to as Bogomilism at the time (at any rate not in the oldest Greek and Slavic sources). In the opinion of certain scholars, the entire period between the Christianization of Bulgaria in the second half of the $9^{\text {th }}$ century and the reign of Peter (as well as the earlier times before and after the founding of the Bulgarian state in 681) can be conceived as the 'prehistory' of this neo-Manichaean movement, or as the gradual formation of a doctrine influenced by Early Christian dualist thought (above all Gnosticism), Iranian dualism, Thracian Orphic mysteries, Manichaeism and later neo-Manichaean doctrines - Massalianism and Paulicianism ${ }^{9}$. It can be surmised that the new heresy was indeed closely tied to Man-

6 For recent research on the reign of Peter and the Bulgaro-Byzantine relations in the middle of the $10^{\text {th }}$ century see: M.J. LeszKa, Wizerunek pierwszego państwa bułgarskiego w bizantyńskich źródłach pisanych (VIII - pierwsza połowa XII wieku), Łódź 2003 [= BL, 7], p. 124-138; И. Билярски, Покровители на Царството. Св. ијар Петър и св. Параскева-Петка, София 2004.

7 И. Билярски, ор. cit., p. 19.

8 The oldest liturgical texts devoted to the tsar saint are found in Bulgarian manuscripts dating back to the early $13^{\text {th }}$ century, which means that the cult must have arisen much earlier. See: И. Билярски, op. cit.,p. 21-42.

9 Cf.: I. DuJČEv, I bogomili nei paesi slavi e la loro storia, [in:] IDEM, Medioevo bizantinoslavo, vol. I, Roma 1965, p. 251-282. The article was originally published in: Atti del Convegno internazionale sul tema 'L'Oriente cristiano nella storia della civiltà', AANL 62, 1964. Some researchers opine that when 
ichaeism and Paulicianism - religious movements that had already terrified Peter's father, tsar Symeon I (913-927), in his own time - if we assume that a certain anti-heretic fragment of the Hexameron by the $10^{\text {th }}$ cent. Old Bulgarian writer John Exarch, who worked in Symeon I's court ${ }^{10}$, indeed refers to the Manichaeans ${ }^{11}$. It is acknowledged, however, that Manichaeism ceased being a threat to orthodox Christianity in the Byzantine Empire after the $5^{\text {th }}-6^{\text {th }}$ century. Regardless of this, in later Byzantine and Slavic legal, liturgical and polemical texts the term "Manichaeans" is still traditionally used in reference to adherents of other heterodox dualist doctrines - predominantly the Paulicians and the Massalians. Did the Old Bulgarian author have such a meaning in mind as well? That is, did he use the word "Manichaeans" to denote the followers of another dualist heresy that had appeared in the Bulgarian lands? Moreover, did John Exarch specifically refer to the Bogomils (as suggested by M. Loos), which would mean that the origins of the Bogomil heresy have to be sought not within the reign of Peter, but earlier - already in the times of Symeon? The answer to these significant questions is not directly related to Theophylact's letter; what needs to be emphasized is that already by the times of Peter, neo-Manichaean dualist doctrines had become deeply entrenched in the Bulgarian territory, putting the orthodox Christian religion in serious jeopardy.

The patriarch of Constantinople was not a typical representative of upper clergy. The fourth son of Romanus Lecapenus, appointed for the post (according to the will of his father)at the age of 16 , was more interested in horseflesh than in theology; in 954 the Patriarch met with a severe riding accident and thenceforward he was incapable of work ${ }^{12}$. It is assumed that the letter was written and sent to the Bulgarian tsar before this date.

Peter I had sent two inquiries to Theophylact, asking what measures he should take in order to combat the heresy emerging in his empire. His letters have not been preserved; what survives is the second of Theophylact's responses - or rather

considering the influence of neo-Manichaean heresies on the territories of the First Tsardom, one should also take into account the dualist elements of the Proto-Bulgar religion, themselves imported from Zurvanism. Cf. B. Hamilton, The Cathars and Seven Churches in Asia, [in:] Byzantium and the West c. 850 - c. 1200: Proceedings of the XVIII Spring Symposium of Byzantine Studies. Oxford, Amsterdam 1988, p. 284-290; Y. SToyanov, The Other God: Dualist Religions from Antiquity to the Cathar Heresy, New Haven-London 2000, p. 125-161.

10 On John Exarch see: KME, vol. II, p. 169-194.

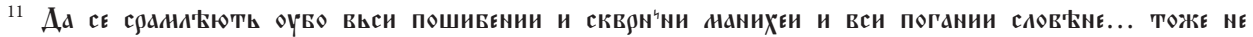

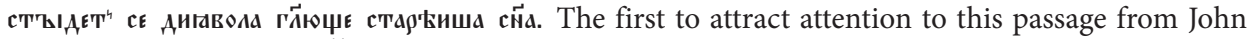
Exarch's Hexameron was Й. Иванов, Богомилски книги и тегенди, repr. София 1970, p. 20. Сf. the analysis of the fragment in: M. Loos, Le pretenduté moignage d'untraité de Jean Exarque in titulé "Šestodnev" et relative aux Bogomiles, Bsl 1, 1952, p. 59-88.

12 S. Runciman, The Medieval Manichee: A Study of the Christian Dualist Heresy, Cambridge 2003, p. 67-68. On Theophylact cf. also A. KAZHDAn, Theophylaktos, [in:] ODB, vol. III, p. 2068. 
a response penned in his chancery by chartophylax John and signed by the patriarch. I. Dujčev presumes that the rejoinder to Peter's original letter must have been too abstract, for which reason the Bulgarian tsar decided to send one more inquiry, requesting from Theophylact concrete directions on how to fend off the heretics ${ }^{13}$.

The text of the letter has a tripartite structure. In the opening, the patriarch applauds Peter's devotion to the Christian faith, also making a point of alluding to the family connections between the Bulgarian and the Byzantine courts (Peter's wife was Theophylact's niece): A faithful and pious soul, my spiritual son, best of kinsmen and most illustrious, is a great matter...

Thus, the initial part contains conventional phrases typical for an official letter; nevertheless, here already the stance of the Church with regard to heretics (or, more precisely, the relationship of canon law to secular legislation) is laid out clearly. Extolling the tsar's Christian virtues, the patriarch emphasizes that the Church should nurture the souls of the faithful, but ecclesiastical authorities cannot take over the prerogatives of the secular administration: it is the ruler who cuts off the roots ${ }^{14}$ of the accursed devil, and it is civil law that ensures that the multi-headed hydra of impiety perishes in holy fire. To be sure, the phrases cited here can be treated as metaphors, skillfully woven into the opening of the letter. Importantly, however, they prove to be more than a mere rhetorical device when viewed in the context of the text as a whole - in the later parts of the letter the basic principle of the Church's non-interference with secular legislation is defended again:

$\ldots$ as for those who persist in vice and suffer from the disease of impenitence, the Church of God cuts them off totally like gangrenous and deadly limbs, handing them over to immediate punishment and anathema as well. The laws of the Christian state - since, $\mathrm{O}$ most prudent of men, you asked me to tell you about them - inflict death on them, judging the penalty a capital one, especially when they see the evil creep and extend widely, harming many.

The Church issues an anathema against the heretics, whereas the death sentence is pronounced in accordance with secular laws. This is not an original view of Theophylact; the actual author of the letter, chartophylax John, draws on Byzantine legal documents (the Ecloga privata aucta according to I. Dujčev ${ }^{15}$ ), prescribing the death penalty for heretics.

At the end of the opening we find a phrase that has been commented on extensively in the research on Bogomilism:

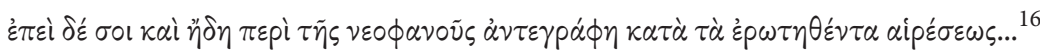

13 I. DuJČEv, L'epistola sui Bogomili..., p. 296-298.

${ }^{14}$ This and the following fragment are omitted from the edition in Christian Dualist Heresies...

15 On the codex Ecloga privata aucta, a compilation of previous legal codices: Ecloga ( $8^{\text {th }}$ cent.) and $E c$ loga aucta, cf. the respective entries of L. BURGMANn in: ODB, vol. I, p. 673.

${ }_{16}$ I. DujčEv, L'epistola sui Bogomili..., p. 311. 
Apart from revealing the existence of the previous, now lost, correspondence between Peter and Theophylact, the letter also features a direct reference to the re-

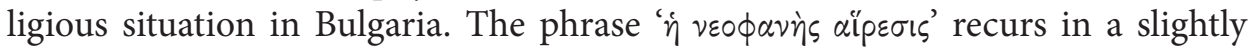
changed context further in the letter, in the tenth anathema:

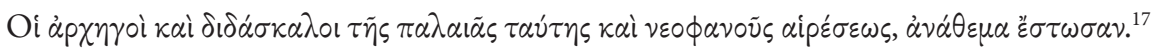

It should be analysed in conjunction with the opinion expressed by the theologians from the patriarch's chancery that the heresy which has newly appeared is not a complete novelty, but an amalgam of Manichaean and Paulician teachings:

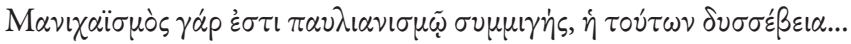

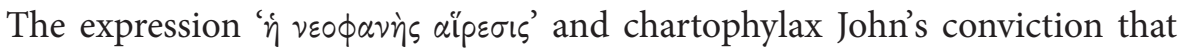

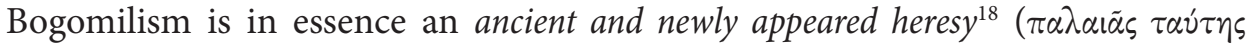

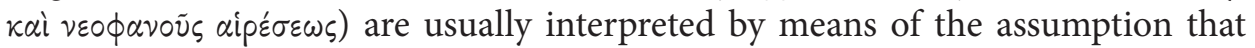
the actual situation in Bulgaria was unknown at the patriarch's chancery, and that the 'original' quality of the heresy was not apprehended in Constantinople. Hence, the letter was composed based on the previously existing Byzantine anti-heretic literature:

He [Theophylact - G.M.], however, was well acquainted with the anti-heretic literature which existed in Byzantium, notably the works of Timothy the Presbyter against the Manichaeans as well as the anti-Paulician texts by Peter of Sicily and patriarch Photius. Consequently, when expounding the Bulgarian heresy and pronouncing an anathema on its teachers, he makes it clear that the heresy is nothing more than a continuation of Paulicianism, with an admixture of Manichaean dogmas ${ }^{19}$.

Such an approach requires some clarification, however. It can be surmised that the two lost letters of Peter contained detailed information on the Bogomils, since - as long as I. Dujčev is correct in supposing that the Bulgarian tsar had asked the patriarch for specific guidelines on how to counter the heretics - we would expect him to have included a thorough description of their doctrine. In such an account, he would presumably have mentioned the founder of this neo-Manichaean movement, the priest Bogomil, whose name was (according to most historians) transferred onto his disciples. There is no basis for assuming that the heresiologists

\footnotetext{
${ }^{17}$ Ibidem, p. 314.

18 The fragment is omitted from the edition in Christian Dualist Heresies...; the English text is cited from: D. Овоlensky, The Bogomils: A Study in Balcan Neo-Manichaeism, Cambridge 1948, p. 115.

19 Д. Ангелов, Богомилството в България, София 1969, p. 39. For critical editions of the aforementioned works by Peter of Sicily and Photius, cf. Les sources grecques pour l'histoire des Pauliciens d'Asie Mineure, ed. et trans. Ch. Astruc, W. Wolska-Conus, J. Gouillard, P. Lemerle, D. Papachryssanthou, J. Paramelle, TM 4, 1970, p. 7-67 and 99-183. For an English translation of Peter's History together with an extensive commentary cf.: Christian Dualist Heresies..., p. 65-92.
} 
in Constantinople were not aware of the state of affairs in Bulgaria: had the lost letters of Peter contained information on Bogomil and the basics of his doctrine, chartophylax John should have mentioned both the name of the emergent heresy and the originality of the Bogomil teachings with regard to the other neoManichaean heresies. Still, having analysed the letters, he did not come to the conclusion that the deviations from orthodox dogmas discussed therein constituted anything new in comparison with the Early Christian dualist religions and neoManichaean teachings widespread in the Byzantine lands; perhaps it is for this reason that he considered Bogomilism an ancient and newly appeared heresy.

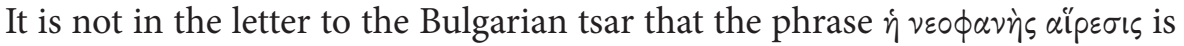
encountered for the first time. In this case as well, chartophylax John makes use of older Byzantine anti-heretic texts. Thus, e.g. patriarch Photius labels the Manichaean heresy as "newly appeared" in the title of one of his polemic works (in the text itself, however, the word "newly appeared" refers to the Paulicians):

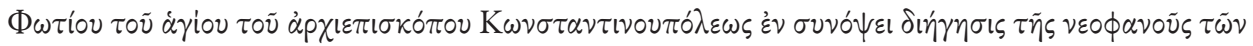
M $\alpha \nu \iota \alpha \dot{\omega} \omega \nu \dot{\alpha} \nu \alpha \beta \lambda \alpha \sigma \tau \dot{\eta} \sigma \varepsilon \omega \varsigma^{20}$.

Later Byzantine sources referring to the Bogomils continue the tradition of calling the Bogomil heresy "new" or "newly appeared", but considering it an unoriginal religious doctrine, adapting beliefs originating from previous neo-Manichaean teachings. In the Letter of Euthymius of the Periblepton (half of $9^{\text {th }}$ cent.), a reliable source of information on the Bogomils of the Byzantine provinces in Asia Minor and the Balkans ${ }^{21}$, the heretics are already referred to as the "Bogomils", and their doctrine is described as influenced by Massalian teachings:

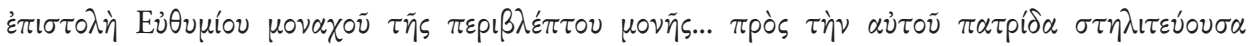

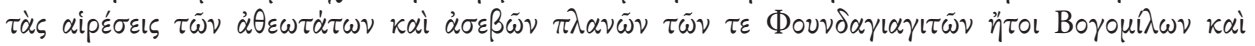
$\mathrm{M} \alpha \sigma \sigma \alpha \lambda \iota \alpha \nu \tilde{\omega} \nu \lambda \varepsilon \gamma \sigma \mu \varepsilon \dot{\varepsilon} \omega{ }^{22}$

The Byzantine monk also remarks that in Asia Minor, the heretics are called "Phundagiagitae", but in the West ( $\Delta \dot{\sigma} \sigma(\varsigma)$, i.e. in the Balkans - "Bogomils".

The Bogomil heresy is depicted in a similar fashion at the beginning of chapter (titulus) 27 of Euthymius Zigabenus' (ca. 1050-1122) prominent anti-heretic work $\Delta \circ \gamma \mu \alpha \tau i \kappa \eta \dot{~} \pi \alpha \nu \circ \pi \lambda i \alpha$, commissioned by Alexius I Comnenus. In the title and first

${ }_{20}$ Cf. TM 4, 1970, p. 121.

${ }^{21}$ Text edition in G. FICKer, Die Phundagiagiten, Leipzig 1908. On Euthymius of Akmonia (or Euthymius of the Periblepton), cf.: M. Jugie, Phundagiagites et Bogomiles, EO 12, 1909, p. 257-262; D. OвоLENsку, ор. сit., p. 175-176; А. СоловЈев, Фундајајити, патерини и кудугери у византијским изворима, [in:] FGHB, vol. I, София 1952, p. 122-126; M. Loos, Dualist Heresy in the Middle Ages, Praha 1974, p. 67-77; Д. Драголловиќ, В. Антиќ, Богомилството во средновековната изворна граѓа, Скопје 1978, p. 172-174; A. K[AZHDAN], Euthymios of Akmonia, [in:] ODB, vol. II, p. 756.

${ }^{22}$ G. FICKER, op. cit., p. 3. 
sentence of the chapter, Zigabenus asserts that Bogomilism arose recently, in our generation. He adds that the movement is akin to Massalianism, with the restriction, however, that certain Bogomil dogmas are original. Especially interesting is the attempt to etymologize the word 'Bogomil' in the title of chapter 27:

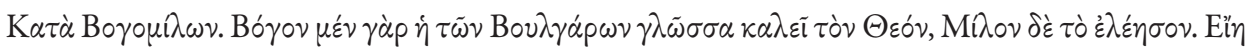

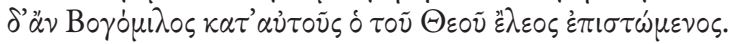

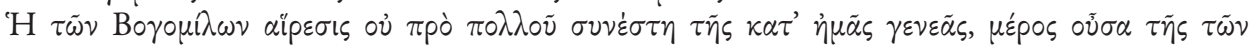

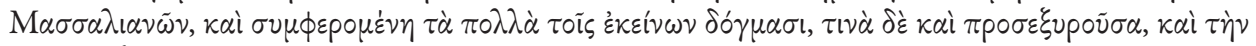
$\lambda \dot{u} \mu \eta \nu \alpha \dot{v} \xi \dot{\eta} \sigma \alpha \sigma \alpha{ }^{23}$

Zigabenus' report is of extraordinary value, as it constitutes first-hand information. The lively theological activity of the learned monk working at the imperial chancery becomes clearly visible during the trial of Bogomil leader Basil the Physician ${ }^{24}$. Zigabenus is present during the hearings and has the opportunity to question Basil; subsequently, he portrays the Bogomil doctrine in accordance with the testimony of the preeminent heresiarch. Not unlike his predecessor from the Peribleptos monastery, he offers a brief comment on the name of the movement. To him, Bogomilism is a Bulgarian heresy: For Bog ( $\delta$ @eós) means 'God' in the Bulgarian language, and milon ( $\dot{\lambda} \lambda \dot{\varepsilon} \eta \sigma o v)$ - 'have mercy'. Neither at the beginning of chapter 27 nor in any further part of the treatise does he mention the name of the mythical founder of the heresy: thus, among them a Bogomil would be someone who obtains God's mercy. One can only speculate on the source from which Zigabenus had this information - he could have hardly been proficient enough in Bulgarian to undertake such etymological investigations on his own. Possibly Basil the Physician himself, in an attempt to mitigate the tsar and the various secular and ecclesiastical officials present at the trial, put forth this explanation of the word, sounding utterly foreign to the Greek ear. On the one hand, the etymology would express the Constantinopolitan Bogomils' respect towards their Bulgarian predecessors; on the other hand, it would provide an alternative interpretation of the word, divergent from the one accepted by most scholars. Accordingly, Bogomil would not be an eponym - it would rather denote 'someone who obtains God's mercy'. The explanation is thus compatible with the religious exclusivism of the Bogomils, who viewed themselves, as opposed to the orthodox Christians, as the ones distinguished by receiving "God's grace".

Furthermore, Zigabenus writes that the Bogomil heresy arose recently, in our generation; it formed part of [the heresy of] the Massalians and in many respects agreed

${ }^{23} P G$, vol. CXXX, col. 1309a.

${ }^{24}$ According to some older investigations, the trial of Basil the Physician took place in Constantinople between 1109 and 1111. For critique of these conclusions, cf.: A. Rigo, Il processo del bogomilo Basilio (1099 ca.): una ricostruzione, OCP 58, 1992, p. 185-211. A. Rigo conjectures that the trial took place ten years earlier and connects it with the events in Byzantium linked to the taking of Jerusalem by the $1^{\text {st }}$ Crusade. 
with their dogmas, but some [dogmas] it additionally invented itself, and increased the corruption. The idea that Bogomilism appeared as late as around the middle of the $11^{\text {th }}$ century is an anachronism, revealing Euthymius' unfamiliarity with the history of this religious movement, known to have originated over a century earlier. It cannot be excluded, however, that he refers to the situation in the Byzantine Empire itself, which the heresy reached at a later time; thus, the Byzantine coreligionists of the Bulgarian Bogomils indeed only established their presence in Constantinople during the time of Zigabenus' "generation".

To my mind, the second sentence is of more importance for the reconstruction of the neo-Manichaean teachings. There, Euthymius compares the Bogomil doctrine to Massalianism, clinging to the time-honoured anti-heretic tradition; he does admit, though, that some of the Bogomil dogmas are innovative. Further, in chapter 27, he also juxtaposes Bogomil beliefs with other heresies - Paulicianism, Sabellianism, and Arianism - referring the reader to the previous chapters of the $\Delta \circ \gamma \mu \alpha \tau i \kappa \eta े ~ \pi \alpha \nu \circ \pi \lambda i \alpha$, where he describes the dualist and trinitarian heresies anterior to Bogomilism in more detail. Frequently, however, he unmasks the heretic cosmogony, dogmas and moral-ethic norms without comparing them with their counterparts in the other dualist movements, ostensibly persuaded that these components of the teaching as laid out by Basil the Physician are original.

A survey of the later Greek sources for Bogomilism does not alter the picture reached so far in any major way. For instance, recounting the trial of Basil the Physician, Anna Comnena writes that in Bogomilism

two doctrines, each known to antiquity and representative of what was most evil, most worthless, now merged together: one might say that the impiety of the Manichaeans, which we have also referred to as the Paulician heresy, was united with the blasphemy of the Massalians ${ }^{25}$.

Anna Comnena was not a first-hand witness of Basil's trial - she learned about the event from the $\Delta \circ \gamma \mu \alpha \tau i k \eta \dot{~} \pi \alpha \nu \circ \pi \lambda i \alpha^{26}$. Still, her testimony is valuable in that it provides yet another example of describing Bogomilism as a contamination of Paulicianism and Massalianism (while Paulicianism itself is regarded as a continuation of Manichaeism).

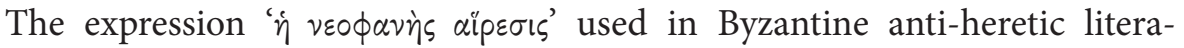
ture in reference to Manichaeism, Massalianism and Paulicianism, also makes its way (as a calque) into Slavic polemical texts - as seen e.g. in the title of Cosmas the Priest's late $10^{\text {th }}$ or early $11^{\text {th }}$ century work known as the Sermon Against

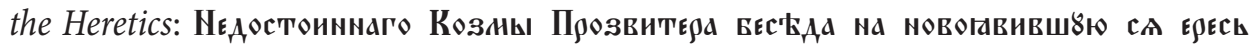

25 Anna Comnena, The Alexiad, trans. E.R.A. Sweter, rev. P. Frankopan, London-New York 2009, p. 455.

${ }^{26} P G$, vol. CXXX, col. 1309a. Cf. also: A. Rigo, op. cit., p. 191-192. 


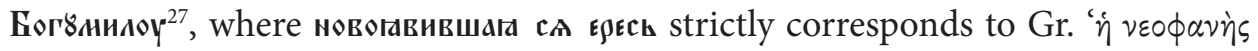

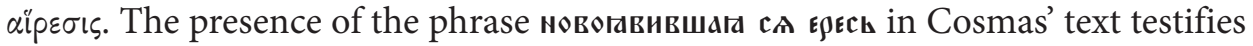
to the author's impressive education - he was presumably conversant in the Byzantine heresiological literature (perhaps even familiar with the Letter of Theophylact itself?), from where he transferred the name of the heresy to the Slavic text.

The connection between Slavic and Greek anti-heretic texts also becomes apparent if we consider the similar ways in which the sources of the Bogomil doctrine are indicated. In the Synodicon of Tsar Boril, written on the occasion of the council against the Bogomils in Tărnovo in $1211^{28}$, its compiler or compilers emphasize that the codex is a translation of a Greek original: tsar Boril ordered the synodicon to be rewritten [i.e. translated, G.M.] from the Greek into his own Bulgarian tongue: Н По сєны Повел' БйГОчистивыи

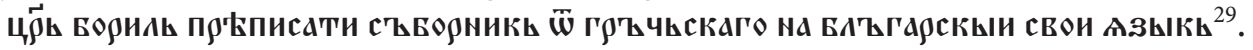
Relying on the Byzantine anti-heretic tradition, the Synodicon of Tsar Boril renounces the Bogomil doctrine as a continuation of Manichaeism: Попа

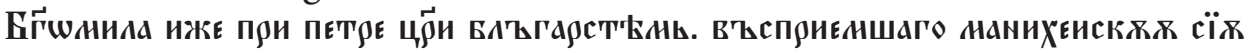

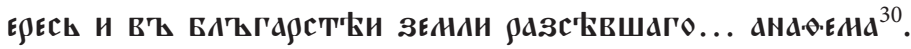

As a blend of Manichaeism, Paulicianism and Massalianism, the heresy of the Bogomils is also stigmatized in other Slavic ecclesiastical legal and liturgical texts, themselves translated or compiled from Byzantine legal sources: in the Kormča, in euchologia and elsewhere ${ }^{31}$. In this connection, one more type of influence of Byzantine works on Slavic legal texts is noteworthy. Greek ecclesi-

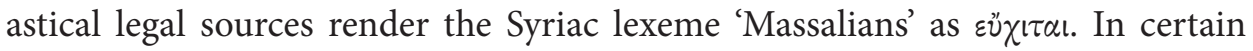
Slavic texts it appears in the form нолитвьници: МАсалигане. иже съқазаюни

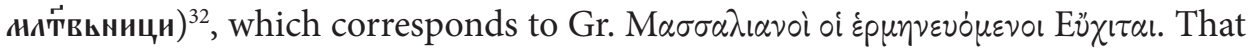
is to say, the principle of handling foreign lexemes is identical: Byzantine authors

27 Cf.: Ю.К. БЕгунов, Козма Пресвитер в славянских литературах, София 1973, p. 297. One should be cautious when interpreting the title of the treatise, however, since most of the copyists from the late $15^{\text {th }}, 16^{\text {th }}$ and $17^{\text {th }}$ century make no mention of either the "newly appeared heresy" or "Bogomil" in

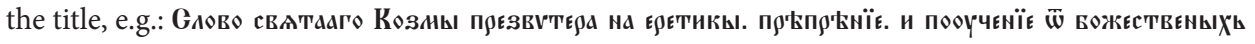

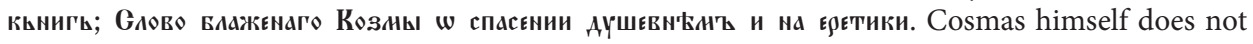
speak of "the Bogomils" or "priest Bogomil" anywhere in the text - he attacks the heretics without calling them by name.

${ }^{28}$ Cf. the new edition of the text in: Борилов синодик. Издание и превод, ed. И. Божилов, А. ТотомАновА, И. Билярски, София 2010.

${ }^{29}$ Ibidem, p. 154.

${ }^{30}$ Ibidem, p. 121-122.

31 As regards newer research on Slavic ecclesiastical legal literature referring to heretics, two studies are especially noteworthy: М. ЦиБРАнсКА-Костова, Кратки сведения за богомилите в южнославянските текстове на иърковното право, БЕ 1, 2004, p. 40-50; М. ЦиБРАнсКА-КостовА, М. РАЙКОВА, Богомилите в църковно-юридическите текстове и паметници, СЛ 39/40, 2008, p. 197-219.

32 Cited from В.Н. БЕнешевич, „Синагога в 50 титулов” и другие юридические сборники Иоанна Схоластика, Санкт-Петербург 1914, p. 670. 
replace the Syriac term 'Massalians' with $\varepsilon \dot{\chi} \chi\llcorner\tau \alpha \mathrm{l}$, whereas in Slavic texts the latter is translated as нолитвьници. The triad 'Massalians - Euchitai - нолитвьници' is likewise attested in another Slavic manuscript - the $15^{\text {th }}$ century copy of Matthew Blastares' Syntagma housed in the library of the Romanian Academy of Sciences, call number 131, k. 18:

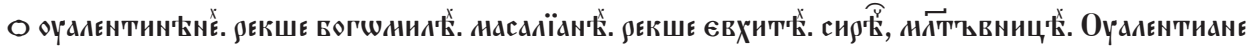

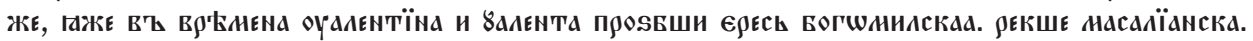

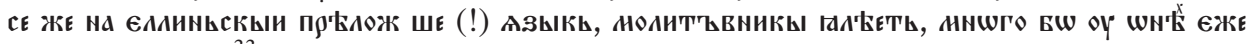
нолитвы инА... 33

The principal part of the letter can be seen as consisting of two mutually interconnected components.

The first one is a concise enunciation of the official position of the Church with regard to three distinct groups of heretics who can be absolved and received back into the Church after suitable penance.

The first group are repentant active teachers; the second - followers of unorthodox religious communities who by their own simplicity and guilelessness are not able to grasp the essence of false doctrines, but obey the orders of the leaders; the third, finally, consists of those who neither preach the heresy nor participate in the rituals, but are attracted to the ascetic habits and ostentatious morality of the heretics.

The two segments are bridged by a practical liturgical suggestion ('O $\delta \dot{\varepsilon}$

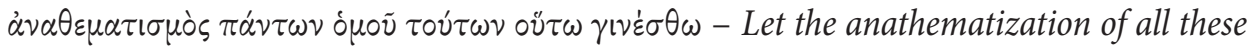
together take this form) and a general formula - an anathema against all those who forsake the orthodox Church and do not respect the dogmas as delineated by the ecumenical councils.

What follows is 14 anathemas referring to dualist religious movements:

- anathemas 1-2: against dualism, the belief in two principles and Satan as the creator of the material world. Radical dualism is the key notion in both the Manichaean and the Paulician doctrine. The anathema does not reveal whether the Bulgarian heretics were radical or mitigated dualists;

- anathema 3: against the "law of Moses", i.e. the Old Testament canon, rejected completely or in part by ancient Gnostic movements (notably Marcion), the Manichaeans and the Paulicians;

- anathema 4: against the renunciation of marriage. Matrimony and procreation were repudiated by Gnostics, Manichaeans and neo-Manichaeans as leading to the multiplication of the despised matter. The negative attitude of the Massalians towards marriage and procreation is also condemned in other Greek sources. Similarly, the orthodox opponents of the Paulicians brought against

${ }_{33}$ Cited from: М. ЦиБРАнсКА-Костова, М. РАЙКовА, op. cit., p. 211. 
them the charges of grave immorality due to their non-recognition of the sacrament of marriage ${ }^{34}$;

- anathemas 5-6: against Docetism - a fundamental accusation against Manichaeans and later dualist religious movements;

- anathema 7: against the neo-Manichaean views on the Eucharist, according to which bread and wine are not transformed into the Flesh and Blood of Christ during the anaphora;

- anathemas 8-9: against the disrespect towards the cult of Mother of God, an attitude common to all neo-Manichaean doctrines, which especially outraged the authors of anti-heretic texts;

- anathemas 10-14: against the chief Manichaean and Paulician heresiarchs.

The anathemas contained in the Letter were closely studied by Ivan Dujčev, Jean Gouillard and Dragoljub Dragojlović35. I. Dujčev justifiably assumes that the text is influenced by older anti-heretic literature, to wit: l'opera di Pietro Siculo, l'opera detta dell'igumeno Pietro, i libri del patriarca Fozio contro i manichei $i^{36}$. The Bulgarian medievalist's hypothesis - no doubt correct, but rather non-specific - was substantiated by J. Gouillard and D. Dragojlović. The anathemas in the Letter of patriarch Theophylact to tsar Peter represent the second version of the so called 'short formula', a reworking of anathemas from the History by Peter of Sicily, with interpolations excerpted from other heresiological works directed against the Manichaeans and the Paulicians (by Cyril of Alexandria, Theodoret of Cyrus and Timothy the Presbyter $)^{37}$.

Less attention has been paid to the first part of the exposition, where the procedure of readmitting penitent heretics back to the Church is laid out. I. Dujčev, similarly to the author of the letter itself, comments on the punishment for the first group of heretics (active teachers - ' $\left.\delta \delta \delta \alpha \sigma \kappa \alpha \lambda \circ{ }^{\prime}\right)^{38}$ in the spirit of canon 19 of the First Council of Nicaea, according to which they are to be rebaptized ${ }^{39}$.

\footnotetext{
${ }^{34}$ S. RUNCIMAN, op. cit., p. 51.

35 I. Dujčev, L’epistola sui Bogomili..., p. 301-308; J. Gouillard, Les formules d'abjuration, TM 4, 1970, p. 185-207; Д. Драголловић, Богомилство на Балкану и у Малој Азији, I, Богомилски родоначалници, Београд 1974, p. 131-132; IDEм, Манихејска формула проклиғағь у словенском преводу, Balc 6, 1975, p. 51-61.

${ }^{36}$ I. DusčEv, L'epistola sui Bogomili.., p. 303. For a critical edition of Peter the Hegumen cf. TM 4, 1970, p. 69-97.

37 J. Goulllard, op. cit., p. 186-187; Д. ДРАГОЈЛОвић, op. cit., p. 131.

38 I. DujČEv, L'epistola sui Bogomili..., p. 298-299.

39 Ibidem, p. 312. I. Dujčev, citing a later Latin translation of the canon (De Paulianistis, qui deinde ad ecclesiam confugerunt, statutum est, ut ii omnino rebaptizentur), emphasizes that the text refers to the Paulicians. However, this seems to be a later interpolation, since the rise of Paulicianism is first mentioned in the sources at the end of the $6^{\text {th }}$ and the beginning of the $7^{\text {th }}$ century. D. OвоLensky (op. cit., p. 115) links this fragment with the heresy founded by Paul of Samosata.
} 
The Bulgarian medievalist does not investigate in great detail the standpoint of the Church towards the second and third categories of repentant heretics (members of unorthodox religious communities and those passively following propagators of dualist doctrines), limiting himself to recounting the relevant part of the letter and enumerating the measures administered to them before they can be reintegrated into the Church: the second group is to undergo anointment, while the third is to serve a 40 -day penance. Notably, the holy orders of the priests classified in both categories remain valid, on condition that they abjure the heresy in writing.

This part of Theophylact's letter to Peter repays closer analysis, since, together with the liturgical direction following it (and introducing the list of anathemas), it sheds fresh light on the sources that served as models for writing new texts at the patriarch's chancery. At the same time, it helps amend certain errors in the interpretation of the letter as regards its structure and contents.

First and foremost, one should mention four canons of the Church councils (one regional and two ecumenical), thematically interconnected and clarifying canon 49 of the First Council of Nicaea. Canons 7 and 8 of the regional Council of Laodicea (343) address the issue of reintroducing contrite heretics to the Church community. Canon 7 prescribes a lighter punishment for members of heretical religious movements whose teachings do not pose a serious threat to the dogmas of the orthodox Church. This refers primarily to some groups with close ties to Arianism: the Photinians, the Novatianists and the related Quartodeciman movement. Having recanted the heresy and learned the Apostles' Creed, they are anointed and admitted to the Eucharist. In the ensuing canon, a more severe punishment is prescribed for the Phrygians (i.e. the Montanists): they are to undergo the full baptism ritual, designed for pagans - including a formal renouncement of their errors and a catechumenate preceding the baptism itself.

A similar division into two categories is found in canon 7 of the second ecumenical council, in Constantinople (381). The first class of heretics encompasses the Arians, the Novatians and the Quartodecimans (mentioned in canon 7 of the Council of Laodicea) as well as supporters of other trinitarian movements: the Macedonian heresy and some groups of the Sabellians. They are to be admitted after anointment, but only after publicly anathematizing their heresy as well as giv-

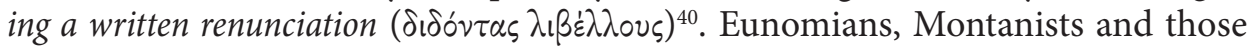
Sabellians qui eumdem esse Patrem et Filium opinantur simul confundentes, et alia gravia et indigna faciunt are to be rebaptized, after a catechumenate, in accordance with how one proceeds with heathens ${ }^{41}$.

${ }^{40}$ Council resolutions cited from: Dokumenty Soborów Powszechnych. Tekst grecki, łaciński, polski, vol. I-II, Kraków 2004-2005; Concilium Quinisextum. Das Konzil Quinisextum, ed. et trans. H. OнмE, Brepols 2006.

${ }^{41}$ On the attitude towards receiving heretics to the Church as expressed in the canons of the councils of Laodicea and Constantinople, cf.: M. Arranz, Les Sacrements del'ancien Euchologe constantinopolitain (2). $1^{\text {ìre }}$ partie: Admission dans l'Église des convertis des heresies oud'autres religions non-chrétiens, OCP 49,1983 , p. 48-49. 
The Council in Trullo (691-692) confirms in canon 95 the resolutions of the councils in Nicaea, Laodicea and Constantinople, at the same time adding further unorthodox religious movements to the list as well as - crucially - defining a third rank of repentant heretics. Arians, Macedonians and Novatians, Quartodecimans and Apollinarists are admitted to the Church following a presentation of certificates. What follows is an extraordinarily interesting sentence, introducing the procedure of rebaptizing followers of the heresies deemed particu-

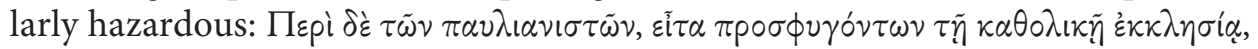

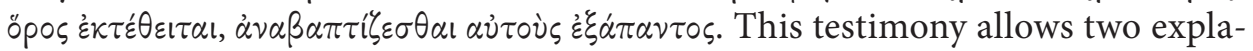
nations. On the one hand, the pronouncement can be treated as a mere restatement of canon 7 of the Council of Nicaea. On the other hand, it can be assumed that before the end of the $7^{\text {th }}$ century the attitude of the Church towards Paulicianism had not yet taken a definite shape and the heresy was not judged to pose an immediate danger. Therefore, it was sufficient for the heretics to undergo anointment and not baptism, which latter procedure is explicitly prescribed for adherents of other dualist doctrines: the Eunomians, the Manichaeans, the Sabellians, the Valentinians and others. The canon also introduces a third category of heretics showing remorse: for Nestorians, Eutychians or Severians a written renouncement of the false doctrine satisfies the requirements for partaking in the Holy Communion, which is equivalent to restoring the severed bond with the Church.

The stance of the orthodox Church regarding dualist heresies - as reflected in the council documents - evolves in a curious way. In the early $4^{\text {th }}$ century (the times of the Council in Nicaea) the attitude towards these heterodox doctrines is quite lucid: heretics are only admitted to the community of the Church by being rebaptized, i.e. even if they have previously received the sacrament of baptism, it is declared null and void. Less than a century later, the perspective on penitent heretics diversifies: for some of them anointment is sufficient (i.e. baptism retains its validity), while for others - those involved in heresies that jeopardize the dogmas and liturgical practice of the Church the most extremely - it is necessary to be baptized just as though they were ordinary pagans, as e.g. in the case ofthe Mon-

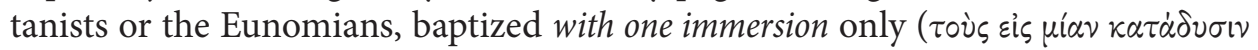

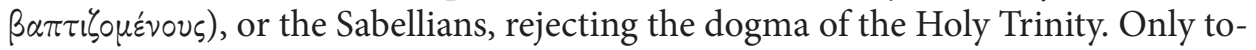
wards the end of the $7^{\text {th }}$ century does canon law announce a third group of repentant heretics: the Nestorians, the Eutychians and the Severians, recognizing the legitimacy of both the sacrament of baptism and of anointment, i.e. considering their deviations from the dogmas as less severe and not leading to their absolute dissociation from the Church. To be sure, their error is considered a mortal sin, but a sin of a Christian, possible to atone for by confessing the blunder and going through a 40-day penance before being admitted to the Eucharist.

A step forward in the research on the process of readmitting heretics to the Church is the above-mentioned study by J. Gouillard, who notes that 
the tripartite categorization of repenting heretics (codified by regional and ecumenical councils) recurs in other Byzantine sources as well: the work of Timothy the Presbyter $\left(8^{\text {th }}\right.$ cent. $)$ and certain texts from the $8^{\text {th }}-9^{\text {th }}$ century, such as the letters of Theodore the Studite or the anti-heretic treatises of patriarch Photius. The first rank (those in need of being rebaptized) includes Manichaeans and Paulicians, although certain hesitation is detectable in the case of the latter, characteristic of the conclusions reached at all councils through Trullanum ${ }^{42}$.

This ecclesiastical legal practice concerning the readmission of heretics to the Church, established after centuries of development, was exploited by chartophylax John in the letter to tsar Peter. The immediate template could have been

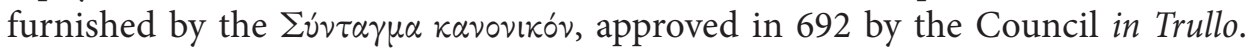
Penned by patriarch Photius in the second half of the $9^{\text {th }}$ century and henceforth known as the Nomocanon of Photius, it comprises the decisions reached at regional and ecumenical councils, Epiphanius of Cyprus' treatise on heresies, the work of Timothy the Presbyter, and in chapter (titulus) 12 it specifies the methods of readmitting heretics to the $\mathrm{Church}^{43}$.

Legal documents of the Church provide general instructions regarding administering ecclesiastical penalties to those led astray by heterodox doctrines, but these instructions only find practical implementation in liturgical codices and euchologia that contain formulae for rebaptizing heretics. In his 1983 article, M. Arranz discusses this rite ( $\left.\tau \dot{\alpha} \xi \xi_{\zeta}\right)$, analysing the text according to the oldest euchologia stemming from both Constantinople and the provinces, as well as some older printed works and later editions ${ }^{44}$. The work of the Spanish liturgist and the reconstruction of the rite allow us to conclude that in the liturgical sources the legal directives of the councils are codified in practice as prescribed by the Nomocanon. Euchological texts classify heretics according to three categories: a) Arians, Macedonians, followers of Dioscorus ${ }^{45}$, some groups of Sabellians, Quartodecimans, Apollinarists (the rite requires a written renouncement of the heresy and an anointment); b) Nestorians and Euchites, i.e. Massalians (a less severe penalty, amounting to a written renouncement and a penance period, after which the former heretics may participate in the Holy Communion); c) Eunomians, baptized with one immersion only, Manichaeans, Montanists and those of the Sabellians who preach subordinationism (admitted to the church according to the procedure for pagans, i.e. they are to be rebaptized) $)^{46}$.

${ }^{42}$ J. Gouillard, op. cit., p. 185.

43 On the Greek Nomocanon and its reception in the Slavia Orthodoxa, cf.: В.Н. БЕнешевич, Древнеславянская Кормчая XIV титулов без толкования, Санкт-Петербург 1906 ['Leipzig 1974]; И. Доврев, Номоканон, [in:] KME, vol. II, София 1995, p. 825-833 (with a rich bibliography).

${ }_{44}$ M. Arranz, op. cit. For the list of sources cited see p. 42-43.

${ }^{45}$ On Dioscorus and his views cf. T.E. Gregory, Dioskoros, [in:] ODB, vol. I, p. 632-633.

${ }^{46}$ M. Arranz, op. cit., p. 53-59. 
The textual dependence of the liturgical directions indicated above on the decisions of the ecumenical and regional councils is self-evident. As an example, let us compare the ritual for heretics as prescribed by the oldest Byzantine euchologium - Barberini gr. 336 from the second half of the $8^{\text {th }}$ cent. ${ }^{47}$ - with canon 95 of the Council in Trullo:

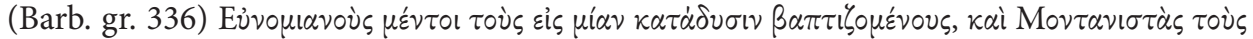

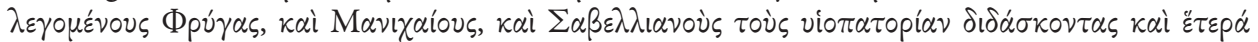

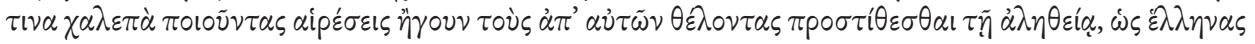
$\delta \varepsilon \chi \sigma^{\mu} \mu \varepsilon \theta \alpha^{48}$.

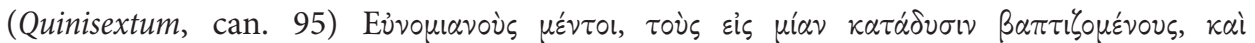

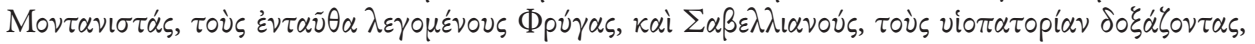

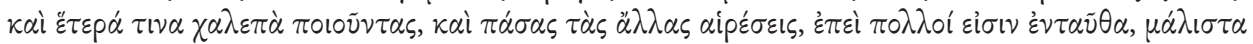

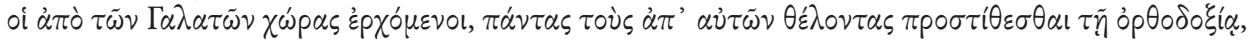
$\omega \varsigma^{\prime} E \lambda \lambda \eta \nu \alpha \varsigma \delta \varepsilon \chi \sigma^{\prime} \mu \varepsilon \theta \alpha$.

It bears emphasizing that the rite as reconstructed by M. Arranz does not mention the Bogomil heresy, which is utterly natural for an euchologium from the late $7^{\text {th }}-8^{\text {th }}$ century, i.e. a time when Bogomilism either did not yet exist or had not yet infiltrated the Byzantine Empire from its Bulgarian cradle. It is striking, however, that Bogomilism is likewise not taken into account (among the heresies whose adherents are obliged to be rebaptized) in later euchologia - both manuscripts and printed works. This is remarkable, because already in the times of Euthymius of the Periblepton and Euthymius Zigabenus, Byzantine anti-heretic literature refers to the Bogomils by their real name and unmasks their doctrine as an alarmingly dangerous dualist heresy.

The reason for this is, perhaps, to be sought in the Byzantine and Slavic heresiological tradition, according to which neo-Manichaean dualist heresies (Massalianism, Paulicianism, Bogomilism) are typically matched with the teachings of their predecessor Mani. This hypothesis can be verified by examining the structure of the rite allowing the heretics to be readmitted to the Church, in which the part on the Manichaeans constitutes an independent entity. The section containing the anathemas that they are to pronounce before being rebaptized is especially sizeable. M. Arranz highlights the fact that ... à partir de BAR... nos euchologes portent un longue texte d'anathème antimanichéen, encore rallongé dans BES COI EBE ${ }^{49}$. The abbreviations used here refer to the following manuscripts: BAR = Barberini gr. 336 (anathemas inf. $141^{\mathrm{v}}-144^{\mathrm{v}}$, p. 156-158 in the edition by S. PARENTI, E. VelKovsKa); BES $=$ Grottaferrata $\Gamma$. $\beta$. I, a provincial euchologium from the $13^{\text {th }}$

47 L’Eucologio Barberini gr. 336, ed. S. Parenti et E. Velkovska, Roma 1995 [= Biblioteca Ephemerides Liturgicae. Subsidia, 80].

${ }^{48}$ Ibidem, p. 155.

${ }^{49}$ M. Arranz, op. cit., p. 60. 
cent.; COI = Paris, Coislin 213, from 1027, the oldest preserved euchologium from Constantinople; $\mathrm{EBE}=$ Athenes $662,13^{\text {th }}-14^{\text {th }}$ cent. The article contains an attempt at a reconstruction of the whole rite of the baptism of Manichaeans based on $\Gamma$. $\beta$. I, Coislin 213 and Athenes $662^{50}$; it is regrettable that the anathemas as found in Barberini gr. 336 were not compared with later texts, preserved in euchologia stemming from Constantinople and the provinces, which could have led to interesting thoughts on the later interpolations. These might contain elements of the doctrines of medieval Manichaean heresies, including Bogomilism, as long as the conjecture that the rite for baptizing Manichaeans was also applicable for Bogomils turns out to be correct.

At this point, it should be noted that post- $12^{\text {th }}$ century Byzantine legal and liturgical texts are not unambiguous with regard to the ecclesiastical penalties imposed on heretics. Antonio Rigo published an anti-heretic text from a Vatican manuscript (Vat. gr. 867, a. 1258/59) ${ }^{51}$, according to which, after confessing in the church and renouncing the Bogomil doctrine before a priest, they pass through a period of catechization, following which they are introduced to the Holy Church of

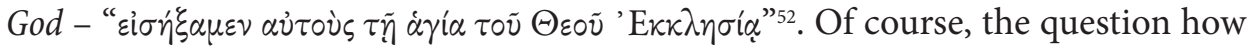
to interpret the phrase 'are introduced' remains open: does it refer to the physical process of leading the heretics into the church building (given that we have

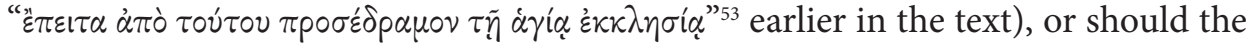
"introduction" in this case be understood as a synonym for the renewed baptism by which they are restored to the Church?

The Letter of patriarch Theophylact to tsar Peter is the oldest, but seemingly not the most informative Greek source for the history of Bogomilism. A closer look at the text reveals the obstacles faced by the reader and scholar of medieval antiheretic texts. A comparison of the Letter...with other Greek and Slavic sources for neo-Manichaean religious doctrines necessitates are evaluation and adjustment of some of the previous findings concerning the position of the letter in the corpus of anti-Bogomil literature. We may draw the following conclusions:

1. Byzantine anti-heretic literature past the $10^{\text {th }}$ century takes advantage of earlier models, in search of similarities between the respective neo-Manichaean dualist movements. In the Letter..., the expression $\dot{\eta} v \varepsilon \circ \phi \alpha \nu \grave{\eta} s$ ai $p \varepsilon \sigma \iota s$, a topos known from earlier anti-heretic works, in expounded in an excessively abstract way, but it is not chartophylax John who is to blame: Bogomilism had not yet become a serious menace to Constantinople, so that the response to Peter's inquiry was designed as pastoral letter, consisting of intertwined quotations from earlier Byzantine polemical literature, council canons, or various legal documents

\footnotetext{
50 L'Eucologio Barberini gr. 336..., p. 156-158.

51 P. Eleuteri, A. Rigo, Eretici, dissidenti, Musulmani ed Ebrei a Bisanzio, Venezia 1993, p. 153-157.

52 Ibidem, p. 156.

${ }^{53}$ Ibidem.
} 
and liturgical rites of the orthodox Church. Viewed in this context, the Letter... is in essence a standard document, a typical product of the patriarch's chancery; it is not conceived as an in-depth investigation into the theological minutiae pertaining to the cosmogony, dogmas and social doctrines of the heretics and the orthodox Church, but rather as a practical tutorial on how to thwart any given neo-Manichaean dualist heresy.

2. When examined against the background of other anti-heretic works, the Letter of patriarch Theophylact to tsar Peter brings to light the fact that the 'new' heresy was treated as 'old' - as a 'reactivation' of earlier gnostic-dualist and neoManichaean movements. This explains why the Letter... contains anathemas based on earlier formulae against dualist heresies (chiefly Paulicianism). Most anti-heretic treatises against the Bogomils lay particular emphasis on their anti-clerical pathos as well as their social and ethical views, which were - perhaps - seen as a novelty of sorts. But even so, the Bogomils were not the first - ardent anti-clerical and anti-feudal views were the trademark of the Paulicians, and it can be surmised that the Bulgarian heretics adopted these ideas from them.

3. The second part of the Letter..., containing an abridged variant of the baptism rite for heretics enriched with fragments of certain legal documents (mostly the Nomocanon), is especially thought-provoking. It could be said that roughly by the $9^{\text {th }}$ century the legal and liturgical sanctions against dualist heterodox doctrines had already been codified and functioned in an essentially unchanged form since then. Gradual change is apparent as regards the categorization of the heretics. The First Council of Nicaea unmistakably recognizes but one category and one kind of punishment - all heretics have breached their union with the church, a deed that can only be repaired by baptism. The subsequent stage is exemplified by the regional Council of Laodicea and the ecumenical Council of Constantinople, where the attitude towards alternative religious movements undergoes diversification: the supporters of milder heresies only need to undergo anointment, while all others must be rebaptized as earlier. Finally, at the end of the $7^{\text {th }}$ century the Council in Trullo announces a third, even less 'offending' class: for adherents of heterodox doctrines who can be readmitted to the Church without either being rebaptized or anointed, but only following a certain period of penance. In any case, Manichaeans and Paulicians (after the $7^{\text {th }}$ century) qualify as those heretics for whom baptism is considered a necessary measure. These legislative norms were finally systematized in the $8^{\text {th }}$ century in the Nomocanon, from where they found their way to Slavic legal codices (the Kormča) and liturgical texts (euchologia), diffusing all over the Slavia Orthodoxa area after the $9^{\text {th }}$ century.

4. The letter also bears a peculiar innovative feature, though not one directly related to the Bogomil heresy itself - rather, it differentiates the text from other Byzantine documents. Chartophylax John transfers the classification of 
heretics and the procedures ensuing from it from the general to the specific level, i.e. he does not speak of several religious doctrines grouped into three categories, but of one category, within which he implements the aforementioned hierarchy. However, he makes use of a different criterion: the degree of commitment to preaching the dogmas of the dualist heresy on the part of the supporters. Correspondingly, the teachers of the heresy are to be rebaptized, ordinary members of the community are to be anointed, whereas uninvolved, passive followers have to do no more than serve a penance.

5. As a final point, it may be noted that the analysis of the Letter of patriarch Theophylact to tsar Peter also raises the more general issue concerning the detailed study of Byzantine and Slavic liturgical texts as a source of information on neoManichaean doctrines. This subject, however, can only be addressed in a separate study.

Translated by Marek Majer

\begin{abstract}
The Letter of patriarch Theophylact to tsar Peter is the oldest, but seemingly not the most informative Greek source for the history of Bogomilism. It is in essence a standard document, a typical product of the patriarch's chancery; it is not conceived as an in-depth investigation into the theological minutiae pertaining to the cosmogony, dogmas and social doctrines of the heretics and the orthodox Church, but rather as a practical tutorial on how to thwart any given neo-Manichaean dualist heresy. It brings to light the fact that Bogomilism, the 'new' heresy was treated as an 'old' one - as a 'reactivation' of earlier gnostic-dualist and neo-Manichaean movements. The letter also features a peculiar innovative feature, though not one directly related to the Bogomil heresy itself: the degree of commitment to preaching the dogmas of the heresy is used for differentiating the situation of the followers. The analysis of the Letter of patriarch Theophylact to tsar Peter raises the more general issue concerning the detailed study of Byzantine and Slavic liturgical texts as a source of information on neo-Manichaean doctrines.
\end{abstract}

Georgi Minczew

Katedra Slawistyki Południowej

Wydział Filologiczny

Uniwersytet Łódzki

ul. Lipowa 81

90-568 Łódź, Polska

georgi.minczew@gmail.com 